\title{
Improving the performance of calcium-containing spray formulations to limit the incidence of bitter pit in apple (Malus $x$ domestica Borkh.)
}

\author{
Alvaro Blanco; Victoria Fernández ${ }^{\text {, J Jesús Val }}{ }^{*}$ \\ Estación Experimental de Aula Dei (CSIC). Avda. Montañana 1005. 50059- Zaragoza. Spain \\ *corresponding autor. Tel: + 34976 716130; FAX: +34 976716145 \\ E-mail address: jval@eead.csic.es
}

\begin{abstract}
Laboratory and field experiments were carried out with apples (Malus x domestica Bork) cv. 'Golden Reinders', to assess the efficacy of sodium salt of carboxymethyl ether of cellulose $(0.5 \%, \mathrm{CMC})$ as an adjuvant for Ca spray formulations containing either Cachloride or Ca-propionate as active ingredient (120 or $250 \mathrm{mM} \mathrm{Ca}$ ). This additive significantly increased the retention of Ca-containing solutions by the apple skin and prolonged the process of drying of the solution at room temperature. Four days after immersion of apples in $0.5 \% \mathrm{CMC}$ plus $\mathrm{CaCl}_{2}$ or Ca-propionate solutions (120 and 250 $\mathrm{mM} \mathrm{Ca}$ ) significant $\mathrm{Ca}$ increases were recorded in the peel and cortex of treated fruits. Application to apple trees of in-season sprays containing $250 \mathrm{mM} \mathrm{CaCl} 2$ plus $0.05 \%$ Tween 20, Ca-propionate (120 and $250 \mathrm{mM} \mathrm{Ca)} \mathrm{plus} \mathrm{0.5 \%} \mathrm{CMC} \mathrm{or} 250 \mathrm{mM} \mathrm{CaCl}_{2}$ plus $0.5 \%$ CMC had no impact on fruit yield and quality, but significantly limited the rate of bitter pit incidence during the following 3-month cold-storage period. Evidence is provided that addition of appropriate adjuvants to Ca sprays can favour the distribution of $\mathrm{Ca}$ into the apple fruit and help to reduce the incidence of Ca-related disorders over the postharvest cold-storage period.
\end{abstract}

Keywords: adjuvants, apple, bitter pit, Ca-propionate, carbxymethylcellulose, calcium sprays, fruit quality, humectancy, spray retention.

\section{Introduction.}

Bitter pit remains as one of the main problems for apple growing industry around the world, particularly in areas where climatic conditions are generally dry. Such physiological disorder which develops during the period of fruit growth (Ferguson et al., 1999), has generally been related to calcium (Ca) deficiency in the fruit cortex ( Ferguson and Watkins, 1989; Fallahi et al., 1997).

The low mobility of Ca in the plant poses serious problems to enhance the distribution of this element to the fruit via Ca application to the root system (Bangerth, 1979). Subsequently, treatment of aerial plant parts with Ca sprays, is recommended and applied in many fruit production areas of the world, either as routine applications to prevent the occurrence of localised Ca deficiency in the fruit or to improve fruit quality (Schlegel and Schönherr, 2002a,b; Lötze et al., 2008; Fernández et al., 2009). The efficacy of Ca treatments supplied to leaves and fruits may be highly variable and currently, many factors involved on the penetration and distribution of Ca within the fruit remain unclear (Saure, 2005; Bai et al., 2008; Val et al., 2008). 
The effects of in-season spraying and/or post-harvest dipping of apple fruits in Ca solutions have been evaluated in various studies in terms of e.g., bitter pit development, $\mathrm{Ca}$ content increase and improved fruit firmness. However, inconsistent results have been often reported (van Goor, 1971; Lidster and Porritt, 1978; Hewett and Watkins, 1991; Neilsen et al., 2005; Lötze and Theron, 2006; Lötze et al., 2008; Val et al., 2008). Recently, Val et al. (2008) showed that in-season $\mathrm{CaCl}_{2}$ sprays led to increased $\mathrm{Ca}$ concentrations in the skin, while no significant changes were measured in the cortex of apples.

Some studies estimated the permeability of apples to Ca solutions either with intact fruits (van Goor, 1973; Mason et al., 1974), fruit discs (Schlegel and Schönherr, 2002a,b) or cuticular membranes (Glenn and Poovaiah, 1985; Harker and Ferguson, 1988; Chamel, 1989; Harker and Ferguson,1991). Regarding the penetrability of apples at different developmental stages, Schlegel and Schönherr (2002a,b) observed that apples were highly permeable to $\mathrm{CaCl}_{2}$ solutions until June drop, the fruits turning significantly less penetrable after such date. The authors suggested that this may be due to the potential contribution of existing stomata and lenticels in the surface of young apple fruits, which would disappear after June drop (Schlegel and Schönherr, 2002a,b).

Penetration of the plant surface by a nutrient solution may occur via stomata, the cuticle, cuticular cracks and imperfections and through trichomes or specialised epidermal cells. Most research efforts in the last decades focused on investigating the diffusion of substances thorough the plant cuticle (Schönherr, 2006). To explain the mechanisms of cuticular penetration of apolar, lipophilic compounds the "diffusion-dissolution model" was proposed (Riederer and Friedmann, 2006). On the other hand, the penetration pathway of hydrophilic solutes through the cuticle is currently not fully understood (Fernández and Eichert, 2009) and the existence of "aqueous pores" as a parallel diffusion mechanism has been hypothesised (Schönherr, 2006). The occurrence of epidermal structures in plant surfaces such as lenticels, stomata or trichomes may significantly influence the rate of absorption of surface-applied agrochemicals. While the significance of the stomatal pathway on the absorption of foliar sprays has been a matter of controversy for many years, recent evidence shows that it can largely contribute to the uptake process (Eichert et al., 2008).

Using young apples and apple segments, Schlegel and Schönherr (2002a,b) suggested the major contribution of stomata and trichomes to the penetration of $\mathrm{CaCl}_{2}$ solutions only at early developmental stages. On the other hand, Harker and Ferguson $(1988,1991)$ and Glenn and Poovaiah (1985) suggested that lenticels in mature apples were preferential sites for the uptake of Ca solutions through the fruit surface.

Several studies showed that surface treatment of cherry fruits with Ca compounds at different stages of development decreased the incidence of cracking (e.g., Glenn and Poovaiah 1987; Brown et al., 1995; Wermund et al., 2005). Furthermore, trials developed by Glenn and Poovaiah (1987) showed that the integrity of the cell wall structure was better preserved in apples treated with $\mathrm{Ca}$, which presented a greater cell-to-cell contact as compared to nontreated fruits.

The effectiveness of Ca sprays is largely influenced by the prevailing environmental conditions, particularly relative air humidity (Schönherr, 2000, 2001). In this regard, Schönherr (2001) pointed out the relevance of the point of deliquescence (POD) of Ca compounds in relation to the rate of diffusion through the cuticle. Bai et al. (2008) showed that foliar treatment with Ca-chloride and Ca-hydroxide in combination with two non-ionic surfactants led to transient changes in the rate of photosynthesis and stomatal conductance of apple and bean leaves. Recently, Kramer et al. (2009a, b) assessed the permeability, drop and 
deposit characteristics of $\mathrm{CaCl}_{2}$ and Ca-acetate formulations applied to tomato fruit and adaxial apple leaf isolated cuticles. They found that surfactants increased the spreading of $\mathrm{Ca}$ within the droplet, and also that the rate of penetration of $\mathrm{CaCl}_{2}$ was always higher than that of Ca-acetate.

Apart from surface-active agents, few studies tested the effect of employing adjuvants to improve the penetration rate and performance of Ca formulations (Mason et al., 1974; Schönherr, 2001; Fernández et al., 2009). Addition of suitable adjuvants into spray formulations can help increase the rate of retention, spreading, penetration and drying of the solution, thereby, improving the performance of fertilisers. Sodium salt of carboxymethyl ether of cellulose (CMC) is a food additive used by the agro-food industry to improve e.g., moisture retention, as a thickener or as an emulsion stabiliser (Ghannam and Esmail, 1998; Nie et al., 2004).

Calcium-propionate could potentially be a good Ca source since it is a small organic salt molecule, which may provide anti-fungal properties. This chemical is also used by the food industry, and has been successfully tested as a fungicide in peach for canker (Biggs et al., 1994) and brown rot (Biggs et al., 1997), and in apple to provide both protective and curative effects against infections caused by Botrytis cinerea (Droby et al., 2003).

The goal of this investigation was to develop laboratory and field studies intended to enhance the uptake of $\mathrm{Ca}$ in apple and thereby reduce bitter pit development and improve storage quality of fruit. The working hypothesis was to evaluate whether the addition of $0.5 \%$ $\mathrm{CMC}$ as formulation adjuvant to be used in combination with Ca-propionate and $\mathrm{CaCl}_{2}$ as active ingredients, provided beneficial effects in terms of formulation properties, fruit tissue Ca increases and fruit quality and storability.

\section{Materials and methods.}

\subsection{Physical-chemical properties of solutions.}

In this experiment, the surface tension (IFT, $\mathrm{mN} \mathrm{m}^{-1}$ ) and the rate of retention of solutions containing the adjuvants 0.5\% CMC (w/v) (ChemWorld S.A., Barcelona, Spain) and Tween ${ }^{\circledR} 20$ (Polyoxyethylene sorbitane monolaurate, Panreac, Barcelona, Spain) were determined in combination (solution) with $\mathrm{CaCl}_{2}$ (Panreac, Barcelona, Spain) or Capropionate (Perstorp_Ltd., Perstorp, Sweden) as calcium sources (120 or $250 \mathrm{mM} \mathrm{Ca}$ ) dissolved in distilled water. The solutions evaluated were: pure distilled water, $0.5 \% \mathrm{CMC}$, pure 120 and $250 \mathrm{mM} \mathrm{Ca}\left(\mathrm{CaCl}_{2}\right.$ and Ca-propionate), $250 \mathrm{mM} \mathrm{CaCl} 2$ plus $0.05 \%$ Tween 20 and finally, 120 and $250 \mathrm{mM} \mathrm{CaCl}_{2}$ and Ca-propionate in combination with $0.5 \%$ CMC.

To record the surface tension, solutions were prepared immediately before measurement to avoid the occurrence of interactions among active ingredients and formulation adjuvants (Fernández et al., 2006). Data were recorded with a DSA 100 Drop Shape Analysis System (Krüss GmbH, Hamburg, Germany) with 10 repetitions per treatment.

The rate of retention of solutions by the apple skin was estimated after immersion of the outer surface of $23 \mathrm{~cm}^{2}$ fruit discs, making sure that the fruit cortex was not wet during the process. Discs were weighed before and after immersion in the treatment solutions and the rate of retention per unit surface was determined as the weight difference after wetting $(\mu \mathrm{L} \mathrm{cm}$ ${ }^{2}$ ), with 5 repetitions. The time at room temperature (30-40\% relative air humidity and 20-23 ${ }^{\circ} \mathrm{C}$ ) until dryness of the solutions retained in apple discs was estimated for $2 \mathrm{~h}$ by the nakedeye observations. 


\subsection{Calcium penetration laboratory experiments.}

A preliminary $\mathrm{Ca}$ application trial was carried out with harvested apples to test the effect of $0.5 \%$ CMC in combination with $\mathrm{CaCl}_{2}$ or Ca-propionate. Cold stored, 'Golden Delicious' apples were randomly selected, carefully washed with soap, rinsed with tap water, subsequently washed in $0.1 \mathrm{~N} \mathrm{HCl}$, and finally rinsed in distilled water to eliminate all residues from pre-harvest Ca-applications.

Seven treatments were applied to the fruits, namely: an untreated control, $250 \mathrm{mM} \mathrm{CaCl} 2$ plus $0.05 \%$ Tween 20, $0.5 \%$ CMC alone, $0.5 \%$ CMC plus $120 \mathrm{mM}$ or $250 \mathrm{mM} \mathrm{CaCl}_{2}$ and $0.5 \%$ CMC in combination with either 120 or $250 \mathrm{mM}$ Ca-propionate. The experimental unit was the single apple and treatments were replicated 5 times.

Formulations were applied by immersion of the entire fruit in the treatment solutions for 5 seconds. Thereafter, fruits were kept for 4 days under laboratory conditions $\left(20-23^{\circ} \mathrm{C}\right.$ and 30 $40 \%$ relative air humidity) before tissue mineral element analysis after thorough fruit washing as described above. Afterwards, fruits were processed for mineral element determination.

\subsection{Field experiments.}

A trial was performed during the summer of 2008 in a 'Golden Reinders'/PAJAM1 commercial orchard located in Alfamén (Middle Ebro Valley, Spain). Trees were selected as uniform as possible in terms of tree size and flowering, and had an average trunk girth of 17.9 $\pm 2.1 \mathrm{~cm}$. Based on the results obtained by Val et al (2008), trees were sprayed with 120 or $250 \mathrm{mM}$ Ca-propionate in combination with 0.5\% CMC, and were compared to trees sprayed with $250 \mathrm{mM} \mathrm{CaCl}_{2}$ plus $0.5 \% \mathrm{CMC}$ or $0.05 \%$ Tween 20 , and also with untreated controls. In all, 5 treatments were applied. The experiment was designed as randomized blocks, with 4 replications, and single trees were the experimental unit.

Trees were sprayed to run-off, using in average $1.4 \pm 0.2 \mathrm{~L}$ per tree of solution, paying special attention at targeting the fruits with the fertiliser solutions. Treatment application started on May $20^{\text {th }}$ i.e., 44 days after full bloom (DAFB), and sprays were repeated at monthly intervals, until August $26^{\text {th }}$ (approximately 1 month before harvest). A total of four in-season spray applications were applied to trees during the growing season of 2008.

Samples of five fruits per experimental unit at different dates along the growing season were randomly collected to record their weight and diameter and for mineral element analysis. A first sample was collected on May $8^{\text {th }}$ prior to the $1^{\text {st }}$ application of Ca-sprays. Afterwards, samples were routinely picked 7 days after each date of spray application. Twenty leaves per experimental unit were also randomly harvested around the tree canopy, from the middle of the shoots. Leaf samples were collected 51, 87, 116 and 151 DAFB, and used for biometry and mineral element analysis.

At harvest, (i.e., September18 ${ }^{\text {th }}$ 2008), yield and number of fruits per tree were recorded, and a randomly selected sample of fruits was used for fruit quality traits assessment (fruit length and diameter, flesh firmness (FF; using an Effegi penetrometer fitted with an $11.1 \mathrm{~mm}$ diameter tip), total soluble solids (TTS; using a PR-101 digital refractometer; ATAGO Co., Tokyo, Japan) and juice acidity (TA; g malic acid $\mathrm{L}^{-1}$ juice). Besides, a larger sample (a box of around $12 \mathrm{~kg}$ in average) per experimental unit was also collected and stored under normal cold conditions $\left(4^{\circ} \mathrm{C}\right)$ for bitter pit development evaluation. This was made by recording the number of fruits affected on a monthly basis, and expressing such proportion in relation to the total fruit number for statistical analysis. 


\subsection{Mineral element analysis.}

For mineral element determination, fruits were carefully washed as previously described (Val et al., 2010), and a 1-cm transverse section of the fruit was cut at the equator, the skin was carefully separated from the cortex, and aliquots of each tissue were prepared for analysis. For tissue element determination, peels were finely cut ( $<1 \mathrm{~mm}$ thick) and mixed. A $0.5 \mathrm{~g}$ aliquot was taken for mineral analyses. The cortex of each apple was cut into small pieces and mixed, and a 2-g aliquot was retained for analyses. Fruit tissues were wet digested using $10 \mathrm{~mL} \mathrm{HNO}_{3}$ and $2 \mathrm{~mL} \mathrm{H}_{2} \mathrm{O}_{2}$ on a hot plate. Once the samples were dry, they were dissolved in $10 \mathrm{~mL}$ of $\mathrm{HCl}$ to which $15 \mathrm{~mL}$ of water was added.

For leaf mineral element analysis, 40 leaves from each experimental unit were randomly collected from the mid-section of growing shoots from around the tree canopy. After removing the petioles, the leaf tissue was carefully washed and scrubbed in a liquid soap solution (1\%), rinsed in tap and deionised water to eliminate surface contamination, and finally dried in an oven at $60{ }^{\circ} \mathrm{C}$ for 2 days. The analyses were based on 1-g dry-weight aliquots. Dry-ashing was performed following the methods of C.I.I. (1969) and Pinta and DeWaele (1975) and Ca concentrations were subsequently determined by Atomic Absorption Spectroscopy (Thermo Scientific iCE 3300 AA Spectrophotometer, Cambridge, UK).

\subsection{Statistical analysis.}

Data were analysed by ANOVA and when significant, means were separated by Duncan's multiple range test. Angular transformation of data on bitter pit incidence was made prior to statistical analysis. For each treatment, the quadratic regression of the values was analysed against time, expressed as days of cold storage after harvest.

\section{Results}

\subsection{Physical-chemical properties of solutions}

The surface tension and rate of retention of the formulations used is shown in Table 1. Pure distilled water and $\mathrm{CaCl}_{2}$ solutions had IFT values higher than $71 \mathrm{mN} \mathrm{m}^{-1}$, while pure Capropionate solutions had significantly lower surface tension values ranging from 64.7 to 65.2 $\mathrm{mN} \mathrm{m}^{-1}$ for 120 and $250 \mathrm{mM} \mathrm{Ca}$, respectively. Solutions containing $0.5 \%$ pure CMC had an IFT of $64 \mathrm{mN} \mathrm{m}^{-1}$, all CMC combinations with Ca sources ranging between 60 to $63 \mathrm{mN} \mathrm{m}^{-1}$. For both Ca compounds, solutions containing the highest Ca concentrations (i.e., $250 \mathrm{mM}$ ) had the lowest IFT values.

The lowest rates or retention were determined for $250 \mathrm{mM}$ plus $0.05 \%$ Tween 20, pure 250 $\mathrm{mM}$ Ca-propionate and pure $120 \mathrm{mM}$ Ca-propionate solutions (3.74, 3.94 and $5.1 \mu \mathrm{L} \mathrm{cm}{ }^{-1}$, respectively). The values determined for unformulated 120 and $250 \mathrm{mM} \mathrm{CaCl} 2$ solutions corresponded to 9.9 and $8.2 \mu \mathrm{L} \mathrm{cm}^{-2}$. Pure 0.5\% CMC solutions had higher retention rates $\left(11.4 \mu \mathrm{L} \mathrm{cm}^{-2}\right)$ as compared to the performance of pure water on the apple peel $\left.(7.5 \mu \mathrm{L} \mathrm{cm})^{-2}\right)$. Subsequently, the retention of $\mathrm{Ca}$ treatments by the surface of apples was very much improved by the addition of $0.5 \%$ CMC, especially in the case of Ca-propionate which showed poor retention rates when applied without formulants.

Drying of solutions at room temperature was prolonged in the presence of $\mathrm{CaCl}_{2}$ (point of deliquescence of $32 \%$, Schönherr, 2001) and also when $0.5 \%$ CMC was added to the formulations. Apple surfaces immersed in pure 0.5\% CMC solutions dried after $1 \mathrm{~h}$, in contrast to those dipped in pure distilled water, which dried approximately after $20 \mathrm{~min}$. The external surface of apple discs treated with Ca-propionate-based solutions were totally dry 
after 20-30 min, and the addition of 0.5\% CMC to such Ca-formulations increased the drying period up to 60-70 min.

\subsection{Calcium uptake laboratory experiments.}

A set of preliminary trials, to test the performance of CMC as an adjuvant for Ca compounds was carried out by dipping apples in treatment solutions and analysing $\mathrm{Ca}$ increases in the peel and cortex of the fruits. Dipping apples in Ca-containing solutions led to increased Ca peel and cortex concentrations versus the values recorded for untreated fruits and those immersed in 0.5\% CMC (Table 2). The highest peel Ca concentrations were determined after dipping apples in solutions containing 0.5\% CMC in combination with 120 $\mathrm{mM}$ Ca-propionate, $120 \mathrm{mM} \mathrm{CaCl} 2$ and $250 \mathrm{mM} \mathrm{CaCl}_{2}$.Pulp Ca concentrations of Ca-treated apples were significantly higher than those measured for pure $0.5 \% \mathrm{CMC}$-treated ones.

\subsection{Field experiment.}

This trial was performed to assess the effect of Ca-propionate (120 and $250 \mathrm{mM} \mathrm{Ca}$ ) plus $0.5 \%$ CMC as compared to $250 \mathrm{mM} \mathrm{CaCl}_{2}$ plus either $0.05 \%$ Tween 20 or $0.5 \% \mathrm{CMC}$ under field conditions. The analysis of $\mathrm{Ca}$ in the cortex of the fruits (Fig. 1) showed that the concentration of this element generally decreased as the growing season progressed, and that an increase was observed in $\mathrm{CaCl}_{2}$-treated fruits during the first weeks following the start of the spraying program. By harvest, Ca concentration was greater in the cortex of fruits treated with $250 \mathrm{mM}$ Ca plus CMC. In the peel (Fig. 1), Ca concentrations increased following the application of $\mathrm{CaCl}_{2}$, although in these fruits, the concentration lowered to that of untreated fruits by the end of the growing season. On the contrary, when Ca-propionate was applied, values were close to normal during the growing season and for the $250 \mathrm{mM}$ Ca treatment, an increase was recorded at the time of harvest.

At harvest, no differences in yield, mean fruit weight or productivity parameters were found. However, fruit quality traits showed differences among treatments (Table 3): an increase in flesh firmness was generally associated with Ca-treatments, which was significantly greater in those sprayed with $250 \mathrm{mM}$ Ca-propionate plus CMC.

A large sample of fruits was cold-stored, where development of bitter pit was expected to occur. Data recorded and transformed along the following three months of cold storage showed a cuadratic increase in the proportion of affected apples (Fig. 2). The goodness of fit tests resulted into highly to very highly significance levels, and determination coefficients ranged between 57.10 and 73.28. The results show that apples from trees treated with Caformulations containing CMC as an adjuvant always presented a lower level of bitter pit incidence as compared to those collected from Tween20-treated, or untreated trees.

The evolution of leaf $\mathrm{Ca}$ concentrations along the growing season following the application of foliar Ca sprays was assessed as shown in Fig. 3. It was observed that leaf tissue Ca concentrations increased linearly during the season up to the time of harvest. Comparison of regression lines showed that they were parallel in all treatments, as slopes did not differ from each other, but those obtained from $\mathrm{CaCl}_{2}$-treated trees had significantly greater intercepts than the rest of treatments. 


\section{Discussion.}

In this study the effect of Ca formulations in increasing tissue Ca concentrations, reducing bitter pit and enhancing fruit quality traits was evaluated under laboratory and field conditions. The aim was to induce positive responses in fruits via the application of in-season Ca sprays and by adding the adjuvant CMC to the formulations. Such additive is commonly used in the food industry as thickener, water binder or as emulsion stabiliser (Ghannam and Esmail, 1998).

The efficiency of nutrient sprays is largely affected by the prevailing climatic conditions at the time of treatment, which may limit in time the process of penetration of the spray solution into the fruit (Fernández and Eichert, 2009). For instance, rapid drying of spray solutions can be expected under the warm and dry conditions observed in the summer in many arid and semi-arid areas of the world, such as in NE Spain. Thereby, addition of humectants and stickers, to the formulations such as CMC, may increase the retention of the active ingredient, prolong the penetration process and increase the rate of $\mathrm{Ca}$ distribution within the fruit (Fernández and Eichert, 2009), a hypothesis which was tested in this investigation.

The performance of CMC solutions in combination with $\mathrm{CaCl}_{2}$ or Ca-propionate was evaluated and compared with the results obtained for $\mathrm{CaCl}_{2}$ plus Tween 20 as reported previously (Val et al., 2008). Both Ca compounds had different points of deliquescence (32 \% and $>95 \%$ for $\mathrm{CaCl}_{2}$ and Ca-propionate, respectively; Schönherr, 2001) and the organic salt was selected because it provides antifungal properties (Biggs et al., 1994; 1997), which could induce beneficial effects in terms of avoiding post-harvest disorders.

Initially the physical-chemical properties of the solutions were evaluated under laboratory conditions. Results indicated that addition of CMC increased significantly the rate of retention of Ca-containing solutions by the apple peel, in addition to the humectant effect conferred by this adjuvant. It was concluded that the sticking and water-binding properties of CMC will increase the humectancy and retention of the foliar spray formulation and favour the process of Ca penetration through the plant surface as observed in this investigation.

Development of laboratory dipping trials with 0.5\% CMC and Ca-containing solutions (120 and $250 \mathrm{mM}$ ) provided evidence for the penetration and distribution of $\mathrm{Ca}$ in the apple fruit. Recently, Kraemer et al (2009a) showed that Ca penetration is directly related to the area covered by $\mathrm{Ca}$ within the spray droplet, which was found to vary in relation to the addition of a surfactant. Therefore, it could be also the case that CMC may affect the distribution of $\mathrm{Ca}$ in the drops after dipping apples into the solution or spraying the treatments under field conditions as suggested by Kraemer et al (2009a,b).

A decreasing trend in apple peel Ca concentrations was observed over the growing season regardless of the Ca-treatments applied to the trees. In contrast, cortex Ca concentrations fluctuated during the growing season and reached a maximum between 80 to 110 days after full bloom when fruits were treated with $250 \mathrm{mM} \mathrm{CaCl}_{2}$ (plus $0.05 \%$ Tween 20 or $0.5 \%$ CMC). Similarly, maximal leaf Ca concentrations were recorded after application of both $\mathrm{CaCl}_{2}$ containing formulations (i.e., with CMC or Tween 20) suggesting the higher permeability of apple fruits and leaves to $\mathrm{CaCl}_{2}$ as compared to Ca-propionate as a Ca source. Increased $\mathrm{Ca}$ penetration rates in association with $\mathrm{CaCl}_{2}$ versus other Ca-containing compounds such as e.g., Ca-acetate (Kraemer et al., 2009a,b), Ca-EDTA (Manganaris et al., 2005) or Ca-propionate (Schönherr, 2001) have been previously reported, which can be associated with the lower molecular size and lower point of deliquescence of the salt as compared to the organic compounds (Schönherr., 2001; Kraemer et al. 2009a). 
Application of multiple Ca sprays containing 0.5\% CMC was not detrimental for fruit quality and slowed the development of bitter pit during cold-storage. A reduction in the incidence of post-harvest disorders in apples by the application of in-season Ca sprays as been shown by some authors (e.g., Hewett and Watkins, 1991; Schmitz-Eiberger et al., 2002; Lötze et al., 2008).

Regarding the mechanisms of action of CMC, in addition to its potential to lower the point of deliquescence of the Ca formulation and capacity to increase the retention of the fertiliser by the plant surface as shown in this investigation, it should be added the fact that it may change the distribution of Ca within the spray drop and may also affect the rainfastness of Ca treatments, as suggested by Kraemer et al (2009b). However, more research efforts are required to clarify the mode of action of foliar formulation additives in combination with active ingredients as a strategy to improve the performance of nutrient sprays under field conditions.

\section{Conclusion.}

The use of $0.5 \% \mathrm{CMC}$ in combination with $\mathrm{CaCl}_{2}$ or Ca-propionate increased the rate of retention by the apple peel and solution humectancy, thereby favouring the process on penetration through the plant surface. Highest tissue Ca concentrations were detected when $250 \mathrm{mM}$ Ca formulations were applied to the fruits. Foliar sprays containing 0.5\% CMC plus chiefly $250 \mathrm{mM} \mathrm{CaCl} 2$ or Ca-propionate led to significant decreases in the rate of bitter pit during cold storage. It is concluded that the adjuvant CMC lowered the point of deliquescence of the Ca-containing solutions and increased their rate of retention as assessed gravimetrically under laboratory conditions. However, more research efforts are required to optimise the use of CMC as a spray additive and to understand the mechanisms associated with the penetration and distribution of exogenous Ca solutions in plant tissues and the mode of action of adjuvants regarding such processes.

\section{Acknowledgements.}

This work was financed by MICINN (Spanish Ministry of Science and Innovation) and FEDER funds under the projects INIA, PET2007-09-C5 and AGL2009-08501.

The authors acknowledge the facilities provided by Mr. E. Valero, of "La Rinconada", (Alfamén, Spain) to carry out the field experiment. Work of Victoria Fernández was supported by a "Juan de la Cierva" MEC post-doctoral contract, co-financed by the European Social Fund. Currently, she is supported by a "Torres Quevedo contract” (MICINN-PTQ), also co-financed by the European Social Fund. 


\section{References.}

Bai, R.Q., Schlegel, T.K., Schönherr, J., Masinde, P.W., 2008. The effects of foliar applied $\mathrm{CaCl}_{2} \cdot 2 \mathrm{H}_{2} \mathrm{O}, \mathrm{Ca}(\mathrm{OH})_{2}$ and $\mathrm{K}_{2} \mathrm{CO}_{3}$ combined with the surfactants Glucopon and Plantacare on gas exchange of 1 year old apple (Malus domestica Borkh.) and broad bean (Vicia faba L.) leaves. Sci. Hort. 116, 52-57.

Bangerth, F., 1979. Calcium-related physiological disorders of plants. Ann. Rev. Agric. Food Chem. 11, 204-207.

Biggs, A.R., El-Kholi, M.M., El-Neshawy, S.M., 1994. Effects of calcium salts on growth, pectic activity, and colonization of peach twigs by Leucostoma persoonii. Plant Dis. 78, 886-890.

Biggs, A.R., El-Kholi, M.M., El-Neshawy, S.M., Nickerson, R., 1997. Effects of calcium salts on growth, polygalacturonase activity, and infection of peach fruit by Monilinia fructicola. Plant Dis. 81, 399-403.

Brown, G., Wilson, S., Boucher, W., Graham, B., McGlasson, B., 1995. Effects of coppercalcium sprays on fruit cracking in sweet cherry (Prunus avium). Sci. Hort. 62, 75-80.

C.I.I., 1969. Comite InterInstitutos para el Estudio de Técnicas Analíticas. Métodos de referencia para la determinación de elementos minerales en vegetales. Anal. Edafo. Agrobio. 38, 403-417.

Chamel, A., 1989. Permeability characteristics of isolated 'Golden Delicious' apple fruit cuticles with regard to calcium. J. Am. Soc. Hortic. Sci 114, 804-809.

Droby, S., Wisniewski, M., El Ghaouth, A., Wilson, C., 2003. Influence of food additives on the control of postharvest rots of apple and peach and efficacy of the yeast-based biocontrol product Aspire. Postharvest Biol. Technol. 27, 127-135.

Eichert, T., Kurtz, A., Steiner, U., Goldbach, H.E., 2008. Size exclusion limits and lateral heterogeneity of the stomatal foliar uptake pathway for aqueous solutes and watersuspended nanoparticles. Physiol. Plant. 134, 151-160.

Fallahi, E., Conway, W.S., Hickey, K.D., Sams, C.E., 1997. The role of calcium and nitrogen in postharvest quality and disease resistance of apples. HortScience 32, 831-835.

Ferguson, I., Volz, R., Woolf, A., 1999. Preharvest factors affecting physiological disorders of fruit. Postharvest Biol. Technol. 15, 255-262.

Ferguson, I.B., Watkins, C.B., 1989. Bitter pit in apple fruit. Hortic. Rev. 11, 289-355.

Fernández, V., Diaz, A., Blanco, A., Val, J., 2009. Surface application of Ca-containing gels to improve quality of late-maturing peach cultivars. J. Sci. Food Agric. 89, 2323-2330.

Fernández, V., Eichert, T., 2009. Uptake of hydrophilic solutes through plant leaves: current state of knowledge and perspectives of foliar fertilization. Crit. Rev. Plant Sci. 28, 36-68.

Fernández, V., V. del Rio, J. Abadia, and A. Abadia. 2006. Foliar iron fertilization in peach (Prunus persica (L.) Batsch): effects of iron compounds, surfactants and other adjuvants. Plant Soil. 289: 239-252.

Ghannam, M.T., Esmail, M.N., 1998. Rheological properties of carboxymethyl cellulose. J. Appl. Polym. Sci. 64, 289-301.

Glenn, G.M., Poovaiah, B.W., 1985. Cuticular permeability to calcium compounds in "Golden Delicious" apple fruit. J. Am. Soc. Hortic. Sci 110, 192-195.

Glenn, G.M., Poovaiah, B.W., 1987. Role of calcium in delaying softening of apples and cherries. Postharvest Pomol. Newsl. 5, 10-19.

Harker, F.R., Ferguson, I.B., 1988. Transport of calcium across cuticles isolated from apple fruit. Sci. Hort. 46, 225-233. 
Harker, F.R., Ferguson, I.B., 1991. Effects of surfactants on calcium penetration of cuticles isolated from apple fruit. Sci. Hort. 46, 225-233.

Hewett, E.W., Watkins, C.B., 1991. Bitter pit control by sprays and vacuum infiltration of calcium in Cox's Orange Pippin apples. HortScience 26, 225-233.

Kraemer, T., Hunsche, M., Noga, G.J., 2009a. Cuticular calcium penetration is directly related to the area covered by calcium within droplet spread area. Sci. Hort. 120, 201-206.

Kraemer, T., Hunsche, M., Noga, G. 2009b. Selected calcium salt formulations: interactions between spray deposit characteristics and $\mathrm{Ca}$ penetration with consequences for raininduced wash-off. J. Plant Nutr. 32(10), 1718 - 1730.

Lidster, P.P., Porritt, S.W., 1978. Some factors affecting uptake of calcium by apples dipped after harvest in calcium chloride solution. Can. J. Plant Sci. 58, 35-40.

Lötze, E., Joubert, J., Theron, K.I., 2008. Evaluating pre-harvest foliar calcium applications to increase fruit calcium and reduce bitter pit in 'Golden Delicious' apples. Sci. Hort. 116, 299-304.

Lötze, E., Theron, K.I., 2006. Dynamics of calcium uptake with pre-harvest sprays to reduce bitter pit in 'Golden Delicious'. Acta Hortic. 721, 313-319.

Mason, J.L., McDougald, J.M., Drought, B.G., 1974. Calcium concentration in apple fruit resulting from calcium chloride dips modified by surfactants and thickeners. HortScience 9, 122-123.

Neilsen, G.H., Neilsen, D., Dong, S., Toivonen, P., Peryea, F., 2005. Application of $\mathrm{CaCl}_{2}$ sprays earlier in the season may reduce bitter pit incidence in 'Braeburn' apple. HortScience 40, 1850-1853.

Nie, H., Liu, L., Zhan, F., Guo, M., 2004. Factors on the preparation of carboxymethylcellulose hydrogel and its degradation behavior in soil. Carbohydrate Polym. 58, 185-189.

Pinta, M., DeWaele, G., 1975. Etalons vegetaux pour l'analyse foliare, In: Kozma, P. (Ed.), Le contrôle de l'alimentation des plantes cultivées. Akademiai Kiado, Budapest, pp. 159-172.

Riederer, M., Friedmann, A., 2006. Transport of lipophilic non-electrolytes across the cuticle, In: Riederer, M., Müller, C. (Eds.), Biology of the Plant Cuticle. Blackwell Publishing, Oxford, UK, pp. 250-279.

Saure, M.C., 2005. Calcium translocation to fleshy fruit: its mechanism and endogenous control. Sci. Hort. 105, 65-89.

Schlegel, T., Schönherr, J., 2002a. Penetration of calcium chloride into apple fruits as affected by stage of fruit development. Acta Hortic. 594, 527-533.

Schlegel, T.K., Schönherr, J., 2002b. Stage of development affects penetration of calcium chloride into apple fruits. J. Plant Nutr. Soil Sci. 165, 738-745.

Schmitz-Eiberger, M., Haefs, R., Noga, G. 2002: Enhancing biological efficacy and rainfastness of foliar applied calcium chloride solutions by addition of rapeseedoil surfactants. J. Plant Nutr. Soil Sci. 165:, 634-639

Schönherr, J., 2000. Calcium chloride penetrates plant cuticles via aqueous pores. Planta 212, 112-118.

Schönherr, J., 2001. Cuticular penetration of calcium salts: effects of humidity, anions, and adjuvants. J. Plant Nutr. Soil Sci. 164, 225-231.

Schönherr, J., 2006. Characterization of aqueous pores in plant cuticles and permeation of ionic solutes. J. Exp. Bot. 57, 2471-2491. 
Val, J., Fernández, V., López, P., Peiró, J.M., Blanco, A., 2010. Low oxygen treatment prior to cold storage decreases the incidence of bitter pit in 'Golden Reinders' apples. J. Sci. Food Agric. 90, 536-540.

Val, J., Monge, E., Risco, D., Blanco, A., 2008. Effect of pre-harvest calcium sprays on calcium concentrations in the skin and flesh of apples. J. Plant Nutr. 31, 1889-1905.

van Goor, B.J., 1971. The effect of frequent spraying with calcium nitrate solutions on the mineral composition and the occurrence of bitter pit of the apple Cox's Orange Pippin. J. Hortic. Sci. 46, 347-364.

van Goor, B.J., 1973. Penetration of surface-applied ${ }^{45}$ Ca into apple fruit. J. Hortic. Sci. 48, 261-270.

Wermund, U., Holland, A., Reardon, S., 2005. Cracking susceptibility of sweet cherries in the United Kingdom in relation to calcium application and covering systems. Acta Hortic. 667, 475-482. 


\section{Table 1.}

Surface tension (IFT; $\mathrm{mN} \mathrm{m}^{-1}$ ), rate of retention $\left(\mu \mathrm{L} \mathrm{cm}^{-2}\right.$ ) and estimated drying time (min) at room temperature after dipping the outer surface of apple discs in treatment solutions. Data are means $\pm \mathrm{SE}(\mathrm{N}=10$, for IFT, and $\mathrm{N}=5$ for retention rate and time until dryness)

\begin{tabular}{|c|c|c|c|c|}
\hline Ca treatment & Adjuvant & $\begin{array}{l}\text { IFT } \\
\left(\mathrm{mN} \mathrm{m}^{-1}\right)\end{array}$ & $\begin{array}{l}\text { Retention rate* } \\
\left(\mu \mathrm{L} \mathrm{cm}^{-2}\right)\end{array}$ & $\begin{array}{l}\text { Time until } \\
\text { dryness (min) }\end{array}$ \\
\hline- & Pure water & $73.2 \pm 0.14 \mathrm{i}$ & $7.47 \pm 1.02 a b$ & 20 \\
\hline- & $0.5 \%$ CMC & $64.0 \pm 0.08$ ef & $11.35 \pm 1.05 \mathrm{de}$ & 90 \\
\hline $120 \mathrm{mM} \mathrm{CaCl}_{2}$ & - & $72.4 \pm 0.11 \mathrm{hi}$ & $9.99 \pm 2.46$ cde & 60 \\
\hline $250 \mathrm{mM} \mathrm{CaCl}_{2}$ & - & $71.9 \pm 0.27 \mathrm{~h}$ & $8.82 \pm 2.23$ bcde & 60 \\
\hline 120 mM Ca-Propionate & - & $65.2 \pm 0.63 \mathrm{~g}$ & $5.1 \pm 0.45 \mathrm{a}$ & 28 \\
\hline 250 mM Ca-Propionate & - & $64.7 \pm 0.41 \mathrm{fg}$ & $3.94 \pm 0.27 \mathrm{a}$ & 20 \\
\hline $250 \mathrm{mM} \mathrm{CaCl}_{2}$ & $0.05 \%$ Tween 20 & $46.2 \pm 0.18 \mathrm{a}$ & $3.74 \pm 0.39$ a & 45 \\
\hline $120 \mathrm{mM} \mathrm{CaCl}_{2}$ & $0.5 \% \mathrm{CMC}$ & $63.1 \pm 0.5 \mathrm{de}$ & $10.5 \pm 1.0$ cde & $>90$ \\
\hline $250 \mathrm{mM} \mathrm{CaCl}_{2}$ & $0.5 \%$ CMC & $60.1 \pm 0.1 \mathrm{~b}$ & $9.52 \pm 2.25$ cde & $>90$ \\
\hline 120 mM Ca-Propionate & $0.5 \%$ CMC & $62.9 \pm 0.15 \mathrm{~d}$ & $12.03 \pm 0.86 \mathrm{de}$ & 70 \\
\hline 250 mM Ca-Propionate & $0.5 \% \mathrm{CMC}$ & $61.2 \pm 0.10 \mathrm{c}$ & $12.79 \pm 1.74 \mathrm{e}$ & 60 \\
\hline
\end{tabular}

${ }^{+}$: Within these columns, values followed by same letter indicate no significance differences according to Duncan's Multiple Range Test (P $\leq$ $0.05)$

* the retention rate was determined gravimetrically after and prior to immersion of the surface of apple disks in the treatment solutions 


\section{Table 2}

Calcium concentration (mg $100 \mathrm{~g}^{-1} \mathrm{FW}$ ) in the cortex and skin of untreated apples versus the values recorded 4 days after immersion in: 0.5\% CMC alone or in $\mathrm{CaCl}_{2}$ and Ca-propionate (120 or 250 $\mathrm{mM} \mathrm{Ca)} \mathrm{solutions} \mathrm{in} \mathrm{combination} \mathrm{with} \mathrm{0.5 \%} \mathrm{CMC.} \mathrm{Post-harvest} \mathrm{treatments} \mathrm{were} \mathrm{applied} \mathrm{to}$ ‘Golden Delicious’ apples. Data are means \pm SE $(\mathrm{N}=5)$.

\begin{tabular}{llc}
\hline Treatments & Cortex & Skin \\
\hline Untreated control & $2.02 \pm 0.25 \mathrm{a}$ & $13.69 \pm 1.19 \mathrm{a}$ \\
$\mathrm{CMC}$ alone & $2.12 \pm 0.03 \mathrm{a}$ & $13.73 \pm 1.29 \mathrm{a}$ \\
$120 \mathrm{mM} \mathrm{CaCl}_{2}$ & $4.61 \pm 1.83 \mathrm{~b}$ & $29.99 \pm 3.50 \mathrm{c}$ \\
$250 \mathrm{mM} \mathrm{CaCl}_{2}$ & $3.65 \pm 0.45 \mathrm{ab}$ & $28.42 \pm 2.30 \mathrm{c}$ \\
$120 \mathrm{mM} \mathrm{Ca}-$ propionate & $5.60 \pm 0.69 \mathrm{~b}$ & $32.89 \pm 0.66 \mathrm{c}$ \\
$250 \mathrm{mM} \mathrm{Ca}-$ propionate & $4.41 \pm 0.50 \mathrm{~b}$ & $21.35 \pm 0.66 \mathrm{~b}$ \\
\hline significance & $* * *$ & $* * *$ \\
\hline
\end{tabular}

***: significant at $P \leq 0,001$.

Within columns, values followed by same letter are not significantly different according to Duncan's Multiple Range Test $(\mathrm{P} \leq 0.05)$ 
Table 3

Quality traits of 'Golden Reinders' fruits sampled at harvest and treated with multiple in-season Ca sprays during the growing season. The spray formulations applied to the trees were: $250 \mathrm{mM} \mathrm{CaCl}{ }_{2}$ plus $0.05 \%$ Tween 20, $250 \mathrm{mM} \mathrm{CaCl}_{2}$ plus $0.5 \%$ CMC, $120 \mathrm{mM}$ Ca-propionate plus 0.5\% CMC and $250 \mathrm{mM}$ Ca-propionate plus 0.5\% CMC. Data are means $\pm \mathrm{SE}(\mathrm{N}=10)$.

\begin{tabular}{llll}
\hline Treatments & $\begin{array}{l}\text { Flesh firmness } \\
(\mathrm{N})\end{array}$ & $\begin{array}{l}\text { TSS } \\
\left({ }^{\circ} \text { Brix }\right)\end{array}$ & $\begin{array}{l}\text { Acidity } \\
\left(\mathrm{g} \mathrm{L}^{-1}\right)\end{array}$ \\
\hline Control & $57.1 \pm 1.62 \mathrm{a}$ & $11.9 \pm 0.40$ & $3.89 \pm 0.09$ \\
$250 \mathrm{mM} \mathrm{CaCl}_{2}+$ Tween 20 & $61.8 \pm 2.11 \mathrm{ab}$ & $12.4 \pm 0.21$ & $4.44 \pm 0.31$ \\
$250 \mathrm{mM} \mathrm{CaCl}_{2}+\mathrm{CMC}$ & $63.4 \pm 2.21 \mathrm{ab}$ & $11.4 \pm 0.37$ & $4.21 \pm 0.45$ \\
$120 \mathrm{mM} \mathrm{Ca}-p r o p i o n a t e+\mathrm{CMC}$ & $58.1 \pm 1.14 \mathrm{a}$ & $12.5 \pm 0.48$ & $4.36 \pm 0.10$ \\
$250 \mathrm{mM} \mathrm{Ca-propionate}+\mathrm{CMC}$ & $65.4 \pm 0.62 \mathrm{~b}$ & $11.9 \pm 0.45$ & $4.00 \pm 0.61$ \\
\hline Significance & $*$ & $\mathrm{~ns}$ & $\mathrm{~ns}$ \\
\hline
\end{tabular}

ns, *: non significant, or significant at $P \leq 0.05$,

${ }^{+}$: Within this column, values followed by same letter are not significantly different according to Duncan's Multiple Range Test $(\mathrm{P} \leq 0.05)$ 
Figures:

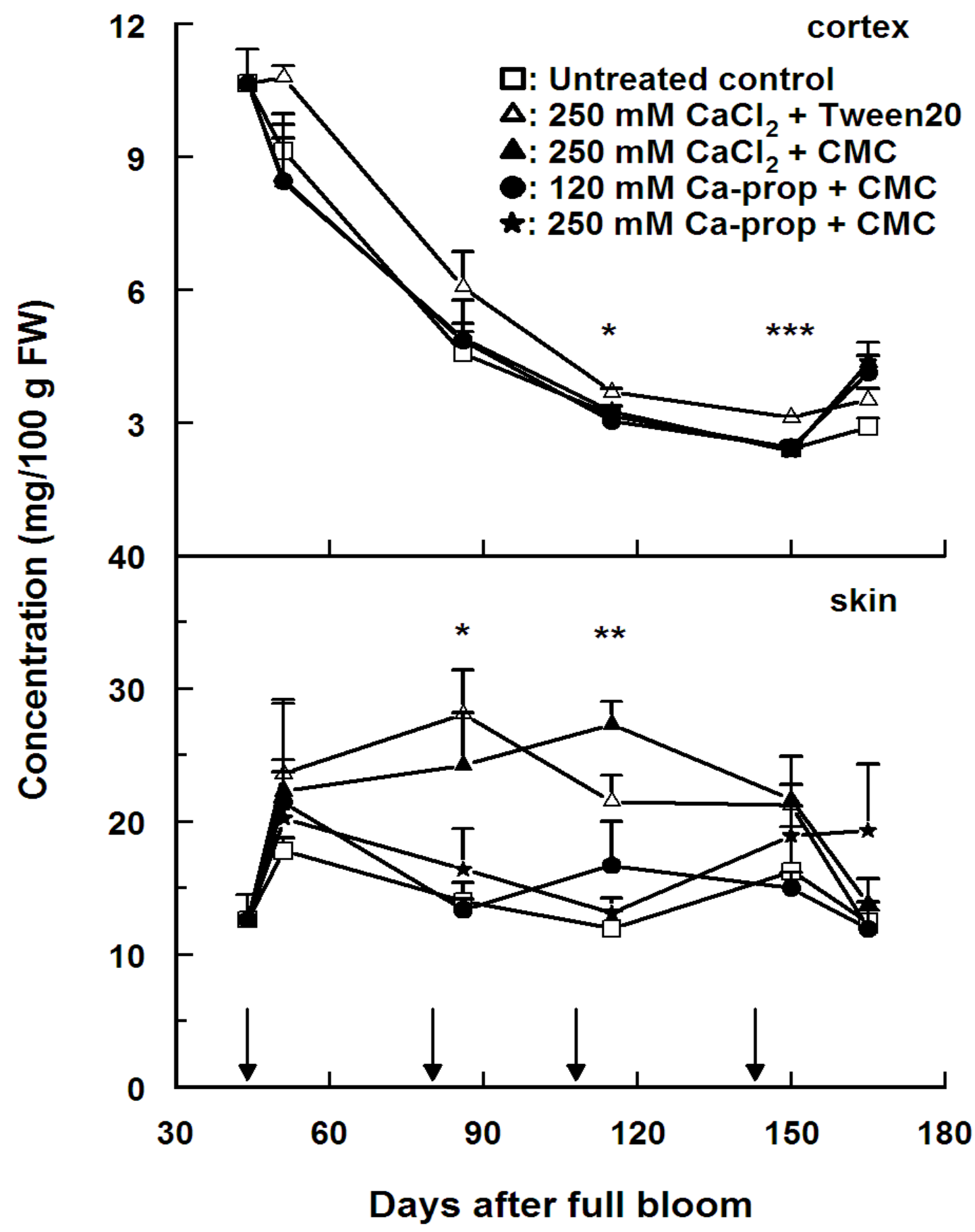

Fig. 1.- Changes in Ca concentration along the growing season in 'Golden Reinders' fruits treated with multiple pre-harvest sprays of $250 \mathrm{mM} \mathrm{CaCl}_{2}$ (plus $0.05 \%$ Tween 20 or $0.5 \%$ CMC), and 120 or 250 mM Ca-propionate plus 0.5\% CMC. Arrows indicate Ca-spray dates. (Mean \pm SE of 4 replicates).

$*$, **, ***: significant at $P \leq 0.05, P \leq 0.01$ or $P \leq 0.001$ respectively, within each date of analysis. 


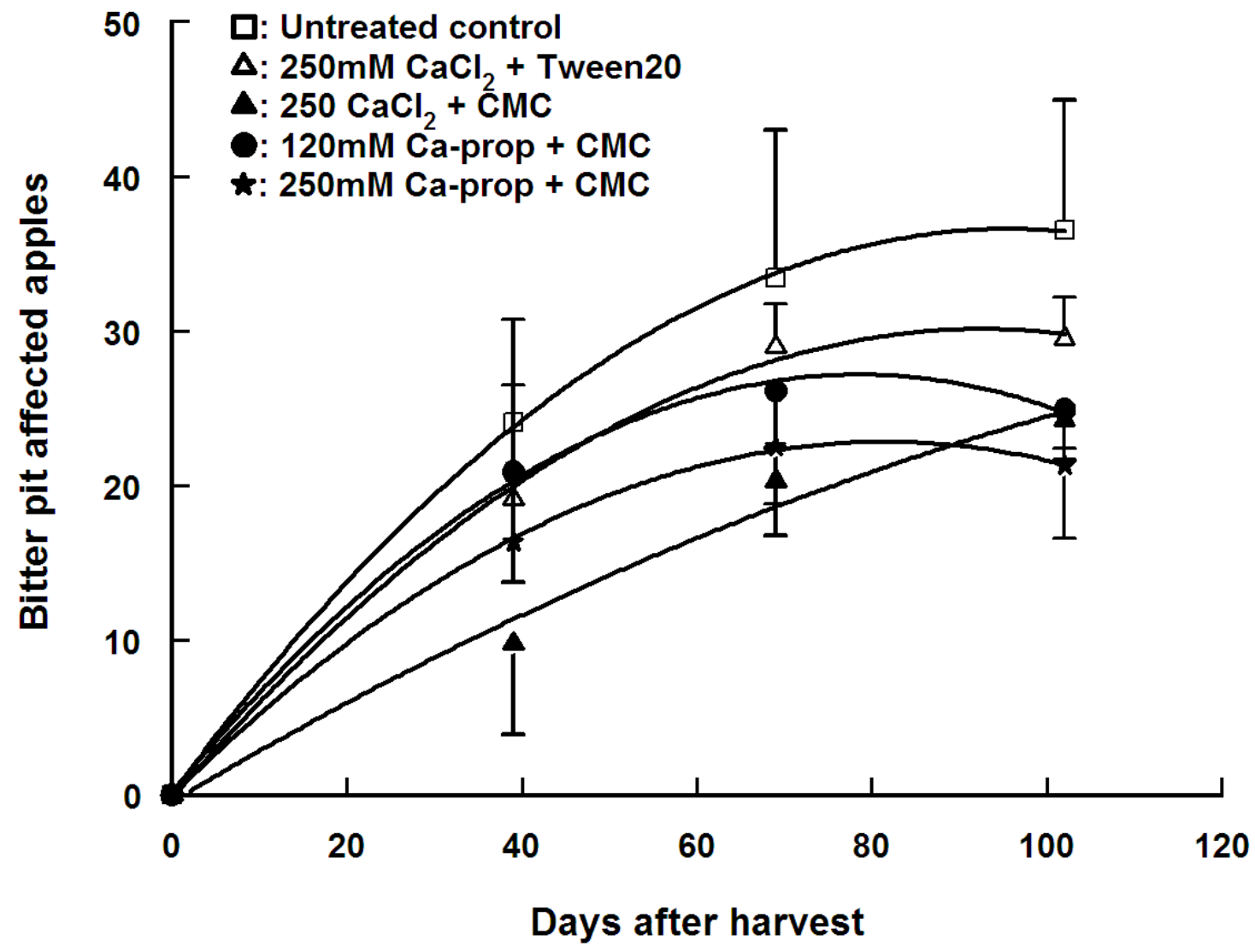

Fig. 2.- Development of bitter pit incidence during cold storage of 'Golden Reinders' apples sprayed with multiple pre-harvest treatments of $250 \mathrm{mM} \mathrm{CaCl}_{2}$ (plus $0.05 \%$ Tween 20 or $0.5 \% \mathrm{CMC}$ ), and 120 or $250 \mathrm{mM}$ Ca-propionate plus 0.5\% CMC. (Mean $\pm \mathrm{SE}$ of 4 replicates). 


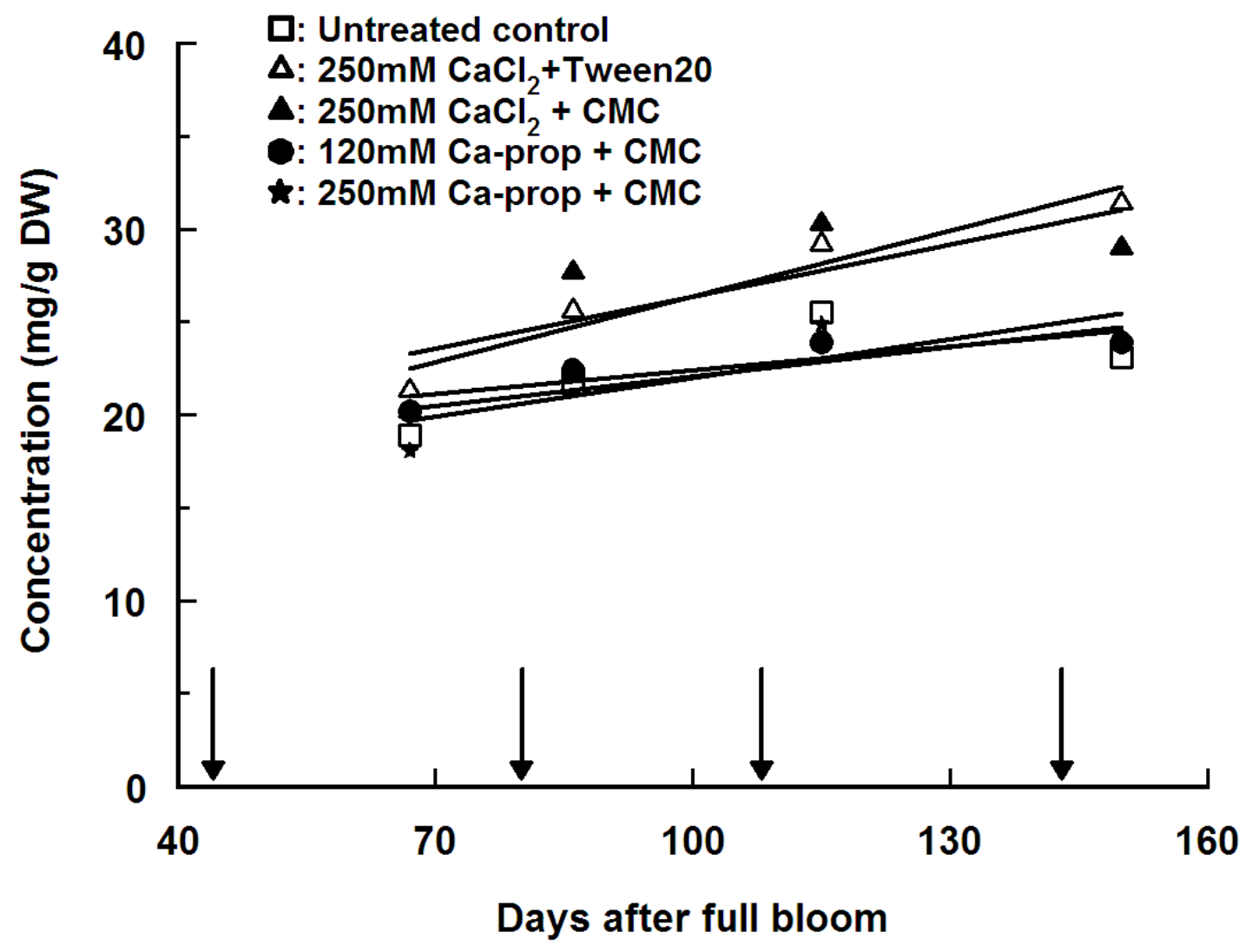

Fig. 3.- Leaf tissue Ca concentrations determined in leaves collected from apple trees sprayed with different $\mathrm{Ca}$ formulations during the growing season. Arrows indicate Ca-spraying dates. (Means of 4 replicates). 